\title{
Re-contemplating the South China Sea Issue: Sailing with the Wind of the 21st Century Maritime Silk Road
}

\author{
Katherine Tseng Hui-yi
}

East Asian Institute, National University of Singapore, Singapore eaithy@nus.edu.sg

\begin{abstract}
With the proposal of the 21st century Maritime Silk Road plan, China has demonstrated its willingness to connect with the rest of the world via cooperation, by sharing its development dividends. Yet, the soaring South China Sea issue possesses great potentials in dampening China's ambitious efforts. The Maritime Silk Road plan is one example. The key is how China can conciliate its South China Sea position, which sees a territorialization trend of the dash-line claim, and the projected posture emphasizing on mutual cooperation and common prospects in the Maritime Silk Road plan. By operating the territorialized dash-line claim in an open-end manner along with subtle management tactics, the South China Sea tensions can be pacified, the Maritime Silk Road plane can also take a successful first step by delivering its words of cooperation and common prospects.
\end{abstract}

\section{Keywords}

International law - South China Sea - Dash-line claim - Territorialization Politicization - Judicialization - Maritime Silk Road plan

\section{$1 \quad$ Introduction}

The South China Sea issue possesses, arguably, great potential to easily ignite furious sentiments among China and regional claimant countries. The tension gets further deteriorated, when more actors, mostly extra-regional countries not bordering South China Sea, are involved. It is a fair observation that 
claimants involved in the South China Sea conundrum today are losing the grandeur sights necessary for a sustainable and mutually-beneficial resolution. In particular, the issue is now overshadowed by two trends. On one hand, there develops an overt reliance on international law when ASEAN claimants assert their claims. Vietnam and the Philippines, while enhancing the credibility of their claims with historical arguments, still emphasize on the importance of international law and law of sea. On the other hand, claimants now are politicizing their narratives, by which the authority will have more leverages ratcheting up nationalistic sentiments laden upon these claims.

As tensions continue to escalate, these two trends seem to be, corollary developments. They also serve to demonstrate the intertwinement between law and politics. On this basis, this article hopes to bring the discussion further to re-contemplate what contemporary international law has and has not offered in due course of the escalation of the South China Sea tension.

Poignantly put, the dispute has not become, paradoxically, more substantiated until law of sea was sealed in the 1980 s. Not defying contributions of the law of sea, maritime order in South China Sea becomes further segregated, which is overshadowed by self-willed state activities under the name of asserting their sovereign claims. In other words, law of sea cannot efficiently solve the stalemate in South China Sea, suggesting the dilemma of applying the Westphalian-minded international law system in a region that is nourished from a set of values with different origins and characteristics.

Under this context, the South China Sea issues merit reconsiderations. In what sense should the South China Sea issues be re-phrased? Are they disputes regarding maritime resources and zoning? How should these territorial contestations be interpreted, when viewed from a grandeur context of the transition of international political and legal order? When narrowing the focus to China, how would the dash-line claim be fleshed out with modern contestations that are not defiant to established Westphalian international system, while serving simultaneously China's interests? This is where the article brings in discussions of Maritime Silk Road plan, as one possible breakthrough to these rather stiff, law-dominated mainstream opinions and stagnant confrontations in South China Sea. This article will re-contemplate the South China Sea issue and China's claim from these perspectives, and how it can be tackled by examining the intersection of Maritime Silk Road plan and South China Sea issue. The key is, to view South China Sea issue not merely a maritime territorial dispute. Instead, by situating South China Sea issue in a broader context of China's new development plan (the "One Belt, One Road" initiative), this grandeur view can help thaw the stalemate by providing an alternative thinking that is able to get rid of the politicized and legalist shackle. 
This article will proceed with an analysis of China's South China Sea claims, highlighting its subtleties, uniqueness and incongruence with contemporary international law and law of sea. Factors looming behind, but with critical impacts, will be identified. The intersection of the Maritime Silk Road plan and South China Sea issue will be studied. Subsequently, proposal of how to conciliate China's South China Sea claim, in particular the dahs-line claim and the Maritime Silk Road plan, along with suggestions of implementation methods will be attempted. This article concludes by trying to vindicate that when a dispute has become intractable-too politicized and overtly judicialized (over- and under-) - to resolve in normal patterns, creative thinking, senses of rationality and practicality, and an open-minded attitude are what is mostly required for sustainable and beneficial resolutions.

\section{Subtlety in China's South China Sea Claims: The Dash-Line Claim}

2.1

\section{The Trend of Territorialization}

Ever since the submission of the dash-line map as an integral part of China's claim in South China Sea to the Commission on the Limits of the Continental Shelf (CLCS) in 2009, ${ }^{1}$ a trend is discernible that China has intended to develop this dash-line claim ${ }^{2}$ to one as a maritime boundary. Several incidents reify this observation.

1 Commission on the Limits of the Continental Shelf (CLCS), Outer limits of the continental shelf beyond 200 nautical miles from the baselines: Submissions to the Commission: Joint submission by Malaysia and the Socialist Republic of Vietnam, 03 May, 2011 (updated), http://www.un.org/depts/los/clcs_new/submissions_files/submission_mysvnm_ 33_2009.htm, accessed 20 March, 2016. Also, See International Tribunal for the Law of the Sea, "ARBITRATORS APPOINTED IN THE ARBITRAL PROCEEDINGS INSTITUTED BY THE REPUBLIC OF THE PHILIPPINES AGAINST THE PEOPLE'S REPUBLIC OF CHINA", International Tribunal for the Law of the Sea Press Release, 25 April, 2013, accessed 20 March, 2016, https://www.itlos.org/fileadmin/itlos/documents/press_releases_english/ PR_191_E.pdf.

2 This trend can be verified via China's arguments in the position paper communicated to the Tribunal on 7 December, 2014, against the Philippine's claims. Briefly summarizing China's positions, two points reify this observation. First, the essence of the subject-matter of the arbitration is the territorial sovereignty over several maritime features in the South China Sea, which is beyond the scope of the Convention and does not concern the interpretation or application of the Convention. Second, Even assuming, arguendo, that the subjectmatter were concerned with the interpretation or application of the Convention, that subject-matter would constitute an integral part of maritime delimitation between the two countries, thus falling within the scope of the declaration filed by China in 2006 in accordance 
First, China has reiterated in several occasions two critical elements in its claim. One is that it has had sovereignty upon all land features lying within the dash line. ${ }^{3}$ The second element is that its claim, "sovereign rights in the waters and sea bed" within the dash-line limit, is thus justified. ${ }^{4}$ Accordingly, patrols and law-enforcement actions conducted by the China Coast Guard ${ }^{5}$ are

with the Convention, which excludes, inter alia, disputes concerning maritime delimitation from compulsory arbitration and other compulsory dispute settlement procedures. Consequently, the Arbitral Tribunal manifestly has no jurisdiction over the present arbitration. See, Position Paper of the Government of the People's Republic of China on the Matter of Jurisdiction in the South China Sea Arbitration Initiated by the Republic of the Philippines, Ministry of Foreign Affairs (China), o7 December, 2014, accessed 20 March, 2016, http://www .fmprc.gov.cn/mfa_eng/zxxx_662805/t1217147.shtml.

3 Ibid. Also, this position has been reiterated in China's official statements. The statement of the spokesperson of Foreign Affairs Ministry in the People's Republic of China, in a press conference held on 29 February, 2012, can be deemed as of referential importance. In that statement, the spokesperson clearly opined that China, neither any other claimant, is not seeking sovereignty upon waters included within the nine-dash line. He nevertheless reaffirmed that sovereignty of all land features within this line has belonged to China since ancient times. See, Foreign Affairs Ministry, Foreign Ministry Spokesperson Hong Lei's Regular Press Conference, People's Republic of China, 29 February, 2012, accessed 20 March, 2016 http:// www.fmcoprc.gov.mo/eng/gsxwfb/fyrth/t910855.htm.

4 Since China is yet to fully clarify its South China Sea claims, in particular the dash-line claim, the relations between this dash line and other parts of China's claim cannot be clearly delineated either. Put it simply, whether it was because of this dash line so that China's sovereign claim over these land features can be justified, or the reverse way round, are falling into a chicken-egg dialectical argument, in which the causation relation cannot be easily and clearly constructed. Yet, different attribution will lead to/require different accounts of justifications. If it is because this dash-line claim, so that China claims also sovereignty over land features within this line, this contestation implies that this dash-line claim generates an entitlement to China so as to justify its sovereignty upon great swathes of waters within this line. A corollary then is what that entitlement refers to. China may need to elaborate further on this. Reversely, if the argument goes the other way round, then the dash-line claim seemingly fits into the dialectics of sovereignty over land features and "historical rights" in South China Sea, as what has been currently debated under the Law of Sea framework. In a word, one significant distinction between these two contestations is, if China aims at developing its own theoretical justification other than law of sea regime. In case of such scenario, China's elaborations in the dash-line claim will be one key point for subsequent reifications and observations.

5 In March 2013, the National People's Congress (NPC) passed legislation to re-constitute State Oceanic Administration (SOA), empowering it to oversee an entirely new maritime law enforcement entity, to be called the China Coast Guard Bureau. The NPC legislation did not set out to create a new division. Rather, the new agency would be to integrate four of the five divisions operated on the sea, dragons: soA's own China Marine Surveillance (CMS); 
reasoned and reasonable, as they are vindications of China's rights and interests in said area. These contentions suggest one enduring Chinese aspiration to the dash-line claim, however implicit, that this dash line serves as a boundary line that entitles China to sovereign rights over all land features lying inside, and also a maritime boundary by which all waters inside the line are under the sovereign jurisdiction of China.

Second, seemingly to echo this aspiration, there emerge burgeoning scholarly efforts, trying to provide reasoned deliberations that the dash-line claim are justified under the law of sea, while serving China's interests as a maritime boundary. ${ }^{6}$ This intellectual brainstorming supports one observation, that the dash-line claim should not be deemed a static concept, but a developing process, which evolves on the basis not only incorporating contemporary norms and international practices, but also regional maritime customs and

the Department of Agriculture's China Fisheries Law Enforcement; the Ministry of Public Security's Border Defense Coast Guard; and the Maritime Anti-Smuggling Police of the General Administration of Customs. On July 22, 2013, a new China Coast Guard Bureau sign was officially inaugurated in Beijing. "The Reconstituted SOA and the China Coast Guard Have Been Set Up" (Zhongzu Hou De Guojia Haiyangju Guapai Zhongguo Haijingju Tongshi Guapai), Central People's Government of the PRC, 22 July 2013, accessed 20 March, 2016, http://www.gov.cn/jrzg/2013-07/22/content_2452257.htm.

6 Chinese scholars have embarked on the mission of fleshing out the dash-line claim with modern terms, not defiant to Law of Sea regime. Amid the plentiful scholarly research, official statements and position papers about China's position in the South China Sea issues, an article may be comprehensive and of referential importance, which is co-authored by a Chinese judge currently serving in the International Tribunal for the Law of the Sea (ITLOS) and a law professor in Qinghua University in Beijing, China, and published in American Journal of International Law in 2013. Zhiguo Gao and Bingbing Jia, "The Nine-Dash Line in the South China Sea: History, Status, and Implications", The American Journal of International Law, 107" 1 (January 2013): 98-124. Also, see Keyuan Zou and Xinchang Liu, "The Legal Status of the U-shaped Line in the South China Sea and Its Legal Implications for Sovereignty, Sovereign Rights and Maritime Jurisdiction", Chinese Journal of International Law, 14:1(2015): 57-77; Michael Ssheng-Ti Gau, "The U-Shaped Line and a Categorization of the Ocean Disputes in the South China Sea", Ocean Development \& International Law Journal, 43:1(2012): 57-69, at $5^{8}$ (stating the map was "first published" by the Republic of China in December 1946); Kuan-Hsiung Wang, "The ROC's Maritime Claims and Practices with Special Reference to the South China Sea," Ocean Development \& International Law Journal, 41:3(2010): 237-252 at 243 (stating the map was "released" in 1947); Jinming Li and Dexia Li, "The Dotted Line on the Chinese Map of the South China Sea: A Note," Ocean Development \& International Law Journal, vol. 34:3-4(2003): 287-295 at 290 (stating the map was "printed" in 1947 and "published" in February 1948); also, Nien-Tsu Alfred Hu, "South China Sea: Troubled Waters or a Sea of Opportunity?" Ocean Development \& International Law Journal, vol. 41:3(2010): 203-213. 
local traditions. ${ }^{7}$ Without doubts, Chinese scholars have already embarked on this mission.

Third, the ongoing arbitration initiated by the Republic of the Philippines against the People's Republic of China in January, 2013, on certain issues in South China Sea, ${ }^{8}$ confirms that the Chinese approach shows a clear lineage to deem the dash-line claim as one of maritime boundary. In this ongoing arbitration, China and the Philippines have had different interpretations. Beijing categorizes the dispute as one regarding territorial attribution and sovereign rights, ${ }^{9}$ while Manila argues that it is the incongruence between the dashline claim and zoning standard in Law of Sea Convention (the Convention hereafter) in dispute. ${ }^{10}$ In other words, distinctions in Beijing and Manila's interpretations indicate that there exist two distinctive concepts, "maritime delimitation" and "maritime limits", which are closely connected, yet inherently different. ${ }^{11}$

\subsection{Maritime Delimitation v. Maritime Limits}

These two intricately interwoven, yet different, concepts easily generate confusions. There is a world of difference between "maritime delimitation" and "maritime limits".12 The former is to describe a "process of establishing lines separating the spatial ambit of coastal state jurisdiction over maritime space", which in due course may involve another state with overlapping legal titles. Therefore, "maritime delimitation" is an operation to be effected between two

$7 \quad$ There have been quite many scholarly discussions in the Chinese approach in the South China Sea dispute. See, for example, Junwu Pan, Toward a New Framework for Peaceful Settlement of China's Territorial and Boundary Dispute (The Netherlands: Martinus Nijhoff, 2009), 163-19o; Keyuan Zou, "Historic Rights in International Law and in China's Practice", Ocean Development \& International Law Journal, 32:2(2001): 149-168.

8 The arbitration is registered with the Permanent Court of Arbitration. See, Permanent Court of Arbitration, "The Republic of the Philippines v. The People's Republic of China", accessed 20 March, 2016, http://www.pca-cpa.org/showpage.asp?pag_id=1529.

9 Supra, note 2, Position Paper (China).

10 Notification and Statement of Claim, The Republic of the Philippines Government, 22 January, 2013, accessed 16 March, 2016, http://www.philippineembassy-usa.org/ uploads/pdfs/embassy/2013/2013-0122-Notification\%2oand\%20Statement\%20of\%20 Claim\%20on\%2oWest\%2oPhilippine\%2oSea.pdf. Also, supra, note 1, "ARBITRATORS APPOINTED IN THE ARBITRAL PROCEEDINGS INSTITUTED BY THE REPUBLIC OF THE PHILIPPINES AGAINST THE PEOPLE'S REPUBLIC OF CHINA".

11 Yoshifumi Tanaka, The International Law of the Sea (Cambridge, U.K.: Cambridge University Press, 2012), 87.

Tanaka, The International Law of the Sea, 87-88. 
or more states, because it aims at clarifying title attribution in areas where legal titles by different sovereigns compete and each claimant tends to exercise jurisdiction over same maritime spaces. In this sense, one essential characteristic of "maritime delimitation" is its international character. The Chamber of the International Court of Justice opined in the Gulf of Maine case, that "No maritime delimitation between states with opposite or adjacent coasts may be affected by [only] one of those states". ${ }^{13}$ In this sense, maritime delimitation is not a unilateral act, but must be effected between a plurality of states.

Further, maritime delimitation is comprised of unusual technical complexity and political relevance. It needs to pay heeds to a compound of factors, straddling various yet relevant scenarios, like legal, political, economic considerations and historical legacies. Meanwhile, technical and environmental factors should also be considered. This intricacy thus turned maritime delimitation into one of the most studied subject, not only by jurists, but hydrographers, geographers, cartographers, and other experts. In this sense, disputes on maritime delimitation usually are replete with a complex of legal and extralegal factors. Yet, case law suggests that the adjudicating body tends to treat geographical parameters as paramount, leaving neglected or only with limited weight to arguments based on population, socioeconomic and security considerations. ${ }^{14}$

The concept of "maritime limits" denotes the establishment that consists of drawing lines that define maritime spaces of a single state, which generally refers to, by its nature, a unilateral act. In law of the sea, the Convention establishes a standard for generating "maritime limits", by dividing maritime spaces into various categories upon their distances from the coast. ${ }^{15}$

In law of sea, the Convention establishes a standard for generating "maritime limits", by dividing maritime spaces into various categories. The first

13 Concerning Delimitation of the Maritime Boundary in the Gulf of Maine Area (Can. v. U.S.), 1984, C.J. 246 (Judgment of Oct. 12), reprinted in 23 I.L.M. 1197 (1984), para. 112(1).

14 Donald E. Karl, "Islands and the Delimitation of the Continental Shelf: A Framework for Analysis", The American Journal of International Law, 71:4(1977): 642-673; Hiran Wasantha Jayewardene, The Regime of Islands in International Law (The Netherlands: Springer, 1990), 259-489; Robert Beckman and Clive Schofield, "Moving Beyond Disputes Over Island Sovereignty: ICJ Decision Sets Stage for Maritime Boundary Delimitation in the Singapore Strait", Ocean Development \& International Law Journal, 40:1(2009): 1-35; Thomas Cottier, Equitable Principles of Maritime Boundary Delimitation (Cambridge, U.K.: Cambridge University Press, 2015), 179-199.

15 This refers to the design of Exclusive Economic Zone, Continental Shelf, Deep Seabed and High Sea in Law of Sea Convention. United Nations Convention on the Law of the Sea, 10 December, 19821833 U.N.T.S. 397. 
category includes internal waters, Archipelagic waters (Part IV), the territorial sea (Part II), straits sued for international navigation (Part III) and buffer zone (known as the Contiguous Zone, Part VI). Farther away, the Exclusive Economic Zone (EEZ, Part v) and Continental Shelf (Part VI) constitute spaces under sovereign rights to marine resources of coastal states. The exclusive usage of marine resources in these areas is monopolized solely to coastal countries. Maritime spaces going beyond EEz and Continental Shelf are the High Sea and deep sea bed. For the High Sea (Part VII) and deep seabed (known as the Area, Part XI), these are common heritages of mankind, on which coordinated management is mandated under an institutionalized mechanism established in the Convention. ${ }^{16}$ In these zones, rules and management measures vary.

Nevertheless, there is no denying that "maritime limits" and "maritime delimitation" may occur in a sequential order, or lending interactive impacts to each other. In a world where the approximately 60 percent of maritime boundaries are still to be defined, ${ }^{17}$ international adjudication has experienced a

16 Ibid., United Nations Convention on the Law of Sea.

17 In many occasions, overlapping claims are common that require limitation efforts, indicating the nature of the event as one for maritime delimitation. The total number of all potential maritime boundaries yet to be delimited stands at a number between 376 and 430. In this context, there is no single sea or ocean that has been fully delimited. Scholarly research shows that the North, Baltic, Black and Caribbean Seas have completed high volumes of maritime delimitation cases. In these areas, more than half of delimitation cases have been drawn. Scholarly interests in estimating maritime boundary cases continue to thrive. In Barbara Kwiatkowska, Equitable Maritime Boundary DelimitationA Legal Perspective, International Journal of Estuarine \& Coastal Law, 3:4(1988): 287-304, Kwiatkowska estimated that there are 276 potential maritime boundaries; in U.N. Secretary General, "Oceans and the law of the sea-Report of the Secretary-General", U.N. Secretary General's Rep. A/59/62 (U.N. General Assembly 59th Session), 4 March, 2004, at paragraph 22, accessed 20 March, 2016, http://www.un.org/ga/59/documentation/listo .html and in Gerald H. Blake, Introduction, in Maritime Boundaries and Ocean Resources, edited by Gerald H. Blak 3 (London: Rowman \& Littlefield, 1987), 1-15, an estimated number of 412 boundaries were claimed; In The Maritime Political boundaries of the World, 2nd ed., in J. R. Victor Prescott V. Prescott and Clive Schofield (eds.) (Martinus Nijhoff, Leiden/Boston, 2006), 245, there are 427 boundaries; In Robin R. Churchill, The Role of International Court of Justice in Maritime Boundary Delimitation, in Oceans Management in the 21st Century: Institutional Frameworks and Responses, edited by A. G. Oude Elferink and D. R. Rothwell (Leiden/Boston: Martinus Nijhoff, 2004), 25-141, at 127, there are 430 boundaries. 
burgeoning of relevant cases, ${ }^{18}$ leading to a process of progressive definition in several ways in maritime delimitation disputes. ${ }^{19}$

The distinction between "maritime delimitation" and "maritime limits" is of such complexity that it leads to two totally different interpretations in ChinaPhilippine South China Sea arbitration.

For China, the essence of the arbitration is territorial sovereignty over several land features in South China Sea. ${ }^{20}$ China opines, accordingly, that the tribunal does not have jurisdiction, since an issue of territorial rights and sovereignty over these features would fall beyond the scope of interpretation or application of the Convention..$^{21}$ For the Philippines, it seeks from the tribunal explanations of what a submerged feature and low-tide elevation can

18 The International Court of Justice has considered numerous cases regarding the extent of maritime jurisdiction of coastal states. Regarding land territorial cases, it has issued decisions in only 14 cases. If counting in other dispute resolution channels, there is a total number of 28 maritime litigations that have been initiated, if not concluded. Yet, this number still pales in comparisons with those resolved via negotiations. See, more, in Coalter Lathrop, "Why Litigating a Maritime Boundary? Some Contributing Factors", in Litigating International Law Disputes: Weighing the Options, edited by Natalie Klein (Cambridge, U.K.: Cambridge University Press, 2014), 230-259; The Maritime Political Boundaries of the World, 2nd ed., edited by J. R. Victor Prescott and Clive Schofield (Leiden: Marinus Nijhoff, 2005), 254; Yoshifumi Tanaka, Predictability and Flexibility in the Law of Maritime Delimitation (Oxford, U.K.: Hart, 2006), 17-126; Bryan T. Sumner, "Note: Territorial Disputes at the International Court of Justice", Duke Law Journal, 53(2004): 1779-1812. For case reference, see also, "List of Contentious Cases by date of introduction", International Court of Justice, accessed, $3_{1}$ December, 2015, http://www.icj-cij.org/docket/ index.php?p1=3\&p2=3; "List of Cases", International Tribunal for The Law of Sea, accessed 20 March, 2016, https://www.itlos.org/cases/list-of-cases/.

19 Igor V. Karaman, Dispute Resolution in the Law of the Sea (Leiden: Martinus Nijhoff, 2012), 169-244. At present there are 195 states in the political map. Inter alia, $15^{2}$ are coastal states, in which 136 are parties to the Law of Sea Convention. All these coastal states have continental shelf ab initio and ipso facto. See, North Sea Continental Shelf Case (Federal Republic of Germany/Denmark; Federal Republic of Germany/The Netherlands), Judgment of 20 February, 1969 (North Sea), I.C.J. Rep. 1969, pp. 3-56, paragraphs 19 and 39, 150 coastal states have provided in their domestic law stipulations of territorial seas, 90 states for the contiguous zones, and 132, for the Exclusive Economic Zone. There are 15 states that have established exclusive fishing zones. See, also, Maritime Space: Maritime Zones and Maritime Delimitation, "Tale of Claims to Maritime Jurisdiction (as at 15 July, 2011)", U.N. Divisions for Ocean Affairs and the Law of Sea website, updated 25 June, 2010, accessed 20 March, 2016, http://www.un.org/depts/los/LEGISLATIONANDTREATIES/ PDFFILES/table_summary_of_claims.pdf.

20 Supra, note 2, Position Paper (China), para. 3.

21 Supra, note 2, Position Paper (China), para. 3. 
generate, in terms of entailed maritime interests, and further, clarification upon what China's dash-line claim can generate regarding its outcome and impact on maritime zoning. ${ }^{22}$

Interpretations held by China and the Philippines of the dash-line claim are featured with polarizing differences highlighted in these two closely related yet distinctive concepts. In essence, it concerns different standards of maritime space management, which consequentially entails different rights and interests. For China, this is an issue of "maritime delimitation", to which territorial sovereignty over land features is a prerequisite for maritime zoning and utilization. On the contrary, for the Philippines, it is an issue of re-confirmation of the standard of "maritime limits" established in the Convention. This explains the mindset of Manila when deciding to go for this political and legal adventure in the Hague. Its consideration/raison d'etre, that if the dash-line claim fell into any of this zoning category in the Convention, is well-justified. What further meddles the water is the words in official statements of China, in which it has upheld the zoning standard established in the Convention, and simultaneously the dash-line claim. ${ }^{23}$

In other words, China respects the maritime limiting/zoning standard established in the Convention, as a universal means for maritime limiting in contemporary days. Yet, by insisting on its dash-line claim, China is also telling the world that there can be an alternative means of drawing maritime limits in South China Sea, which is by this dash-line and historical right claim. A corollary, therefore, will be that this dash-line claim not only serves as a maritime boundary, but also provides a model of how maritime limits are established in South China Sea. In this regard, is this Chinese message/interpretation connoting that the dash-line claim serves a dual role, as a means both for maritime delimitation and maritime limits?

22 Supra, note 10, Notification and Statement of Claim (Philippines). Also, supra, note 1, "ARBITRATORS APPOINTED IN THE ARBITRAL PROCEEDINGS INSTITUTED BY THE REPUBLIC OF THE PHILIPPINES AGAINST THE PEOPLE'S REPUBLIC OF CHINA".

23 The Chinese government has repeated in various occasions that it upholds the Law of the Sea Convention and the regime. See for example, supra, note 3, the statement of Foreign Affairs Ministry spokesperson in the People's Republic of China, 29 February, 2012. Another example is the statement made by incumbent Foreign Affairs Minister, Wang Yi. See Ministry of Foreign Affairs (China), "Foreign Minister Wang Yi on Process of 'Code of Conduct in the South China Sea', People's Republic of China, 5 August, 2013, accessed 20 March, 2016, http://www.fmprc.gov.cn/eng/zxxx/t1064869.shtml. Also, see, supra, note 2, Position Paper (China). 


\subsection{Dual Roles of The Dash Line}

In this context, the subtlety of the dash-line claim should be understood from an innovative perspective, that the dash-line claim has the capacity serving dual functions. On one hand, it is a maritime boundary, which justifies China's sovereignties laid over these land features. This further paves the way to claim that great swathes of waters within this dash line also fall into China's jurisdiction. On the other, this dash line can also be regarded as a Chinese interpretation of a method of generating "maritime limits". Subsequently, the implication is that the dash-line claim, with these dual functions, is an alternative approach of maritime spatial management in South China Sea. Yet, China also signals in many occasions that this dash-line claim is not intended to defy law of sea. ${ }^{24}$

Accordingly, besides viewing it as a maritime boundary, is China also intended to contend that this dash-line claim can serve a method of generating maritime limits in South China Sea, as a regional custom? In this sense, how do China convince regional countries' that the dash line can serve as an alternative means, more preferable to law of sea and more informed with historical characteristics, thus more capable of meeting local needs? Then, a subsequent inquiry is the implication of the juxtaposition of this dash-line approach and the law-of-sea zoning standard. How can this juxtaposition be interpreted? Would this juxtaposition thus overshadow the authority and credibility of the Convention in its aspiration to a universal standard in marine affairs management? Or on the contrary, does it provide a chance for this law of sea regime with a Westphalian mindset to revamp itself by including more regional expediency and local considerations?

Pending replies to these inquiries, this dash-line claim with these dual functions has provoked criticism among claimants and stakeholder countries. For one thing, this dash-line claim may make blurring the distinction between the concept of "maritime delimitation" and "maritime limits". Further, these dual functions may run the risk of deepening the suspicion of other claimants that China, by no means, intends to solve the dispute in the general template of international law and international practices. These worries, even selfperceived, may fester hostilities held against China, which would easily spoil inter-state relations in this region. In this regard, it is one challenging mission for China to flesh out the dash-line claim with elaborations more sensible to modern concepts and practices, while not defiant to established law of sea, general international law and contemporary international practices.

24 This has been repetitively reiterated by China. See, supra, note 3, Foreign Affairs Ministry Spokesperson, Hong's statement, and note 22, Foreign Affairs Minister Wang's statement. Also, see, supra, note 6 . 


\subsection{Implication: Over-Politicization and Extra-Judicialization}

2.4.1 Intertwinement of Politics and Law

The developing intractableness of South China Sea issue, in particular, complexity of the dash-line claim, indicates how the intertwinement of law and politics has actually informed and shaped inter-state disputes.

As explained by Tønnesson, law has re-moudled the South China Sea issue in terms of governmental behaviours, policy discourses and patterns for interstate dialogues and dispute resolution. ${ }^{25}$ Law has, on one hand, accentuated disputes by inducing contestation of overlapping claims, encouraging claimants' behaviours of asserting sovereignty rights, while failed to clarify certain key issues. $^{26}$ However, law has made contributions too, by alleviating the danger of war and constraining claimants from resorting to use of force. One further notable impact is that law and legal justification have become one king clause that all claimants would have embarked on. In past decades since the South China Sea issue was brought back to the front burner in 1990s, law has penetrated diplomatise and policy discourse of all claimants. The emphasis is with such a frequency, that any resolution beyond international law becomes increasingly unlikely and unimaginable. Succinctly put, a trend of overt judicialization is taking place, which in turn is shrinking the alternative and room for dispute resolution in the future. ${ }^{27}$

This law factor has set in to reshape diplomatic practices and policy promulgation of the claimant states. Yet, inquiries remain, as if their policy discourse and position argument are reflecting genuine legalistic thinking, or boiling down to the ground, a mere opportunistic political maneuvering under the disguise of a legal overture. Put sharply, doing law and thinking about law are two things, with polarizingly different reasons/raison d'etre, distinctive outcomes and impacts.

25 Stein Tønnesson, "The South China Sea: Law Trumps Power", Asian Survey, 55:3(2015): 455-477.

26 The Law of Sea Convention has left certain issues in deliberate vagueness. This is so because the consensus was reached among a plenty of countries with diversified national interests and calculations. One most notable issue is the island regime prescribed from Article 121-123. Definitions of islands are crafted with vague words, and distinctions between an island and a rock, unclear. Other issues that require further clarification and amendment, if necessary, are like historical rights and the effect of declarations made under Article 298. See, supra, note 15.

27 Yet, Tønnesson holds a different opinion, "... the law of the sea sets clear limits to what a solution can look like". Also,Yann-Huei Song and Stein Tønnesson, "The Impact of the Law of the Sea Convention on Conflict and Conflict Management in the South China Sea", Ocean Development and International Law Journal, 44:3(2013): 235-269. 
Take one step further, legalistic thinking informing claimants' discourses and positions actually reveals one structural issue that has confronted newlyindependent countries after World War II, and subsequent decades seeing hard struggles against imperialist predation and colonial suppression. Simply versed, the issue regards the incongruence between international legal and political order - nourished and developed in an underbed of Christian tradition and an account of missionary practices — and indigenous culture, tradition and perspectives to how governance is being projected and should be performed at both domestic and regional levels.

In South China Sea, the intertwinement of law and politics not only has been greatly felt in both Chinese and ASEAN capitals, but also has nourished two ostensibly conflicting, yet mutually-eclipsing, trends, namely, overpoliticization and extra-judicialization of the issue. For the former, it refers to a trend that interprets/understands the issue, overwhelmingly, from political lenses. Instead, the latter refers to an over-estimated or under-estimated understanding of the role and influence of law in South China Sea issue. These two trends are mutually-eclipsing, because their relations are largely driven by an interactive dynamism between them. When ASEAN claimants show stronger preferences to legal solutions, China would exercise harsher resistances against it, which recursively push further the issue to one grey zone seeing even more vigorous intertwinement between law and extra-law factors, such as politics and history. In this sense, South China Sea has been further locked into a stalemate. The more legalist these claimants' approaches become, the stiffer the confrontation turns out to be. The more emphasis on political calculations of these claims, rooms for mutually-beneficial solutions get further narrowed down.

\subsubsection{Over-Politicization}

By combining an account of legal developments with a chronology of geopolitical events since 1973, tensions in the South China Sea have been scaled up to certain levels that territorial quarrels among China and ASEAN claimants are in fact dampening, or to the least, interrupting the amicability necessary for inter-state cooperation in many aspects. The lack of effective cooperation mechanism in a variety of issues, such as fishing and maritime environmental administration, is unfortunately one direct outcome. The upshot is for everyone to burden the bitterness, such as intermittent fish run-ins, depletion of and competition for maritime resources, and increasing costs of maritime transportation. Besides the political narrative and populist sentiment in national capitals, these pains have been realistically felt in littoral communities of China and ASEAN claimants because of the loss of lives and livelihoods. 
With heavy maneuvering of political narratives and sabre rattling in South China Sea issues, a grey zone has been created. In this grey zone, claimants tend to maintain certain degrees of vagueness in their positions, which allow them to more efficiently cap the risk of escalations. In other words, this "strategic uncertainty/ambiguity" in the South China Sea has allowed all involved or interested therein to maintain a certain status quo, while managing to neither renounce their own claims, nor engage others' in direct military conflicts. This deliberated vagueness is further sustained on via a series of non-binding initiatives, and forms of dialogue. In this sense, tensions are calculated, with implicit consensus negotiated among all stakeholder countries.

The phenomenon of "over-politicization", has enmeshed everyone holding a stake, great and small.

On China side, territorialization of the dash-line claim in recent rounds of tensions is clearly discernible. The Chinese efforts in response to the arbitration currently ongoing in the Permanent Court of Arbitration re-affirm this observation. ${ }^{28}$ While not rejecting international law and law of sea regime, China has framed its contestations with tinges, however implicitly, of its sufferings and war-torn histories in past centuries (from 1842 to present days). As a consequence, its claim is informed with an overtly large portion of historical arguments and documentary evidences, yet with a shortage of evidences of effective control and consistent administration. ${ }^{29}$ China's approach is delicate, in terms that it is straddling legal and extra-legal scenarios, going beyond simply legal discourses, with its arguments, framed under a combination of deliberations of contextual environment and progressive development of the dispute.

On ASEAN claimants side, theatrics have begun in 2009, when Vietnam, Malaysia, China submitted Note Verbale to the United Nations Committee for the Delimitation of Continental Shelf. ${ }^{30}$ Since then, tensions went up and down, and have become one potential flashpoint that easily topples over efforts for regional developments in various aspects. While sentiments remain boiling in certain claimant countries, it is a totally different picture in the other. This cleavage demonstrates that with disputed subjects remotely-situated and dispersedly-scattered in the sea, where no civilian could easily reach and land, the very "emptiness" of these island (as in people's cognition and memory) makes them the ultimate patriotic symbols, or "logos of nationhood in a global

28 See, supra, note 2, Position Paper (China).

29 See, supra, note 2, Position Paper (China).

30 See, supra, note 1, CLCS Joint submission by Malaysia and the Socialist Republic of Viet Nam. 
media age". ${ }^{31}$ The Southeast Asian politicians have much freedom to define what these territorial conflicts mean to their respective populations.

For example, Vietnam serves how South China Sea claims have evolved to connote more than simply territorial disputes for the claimant country. The significance of South China Sea issue now serves more than territorial disputes for Vietnam in two aspects. For one thing, it provides a standpoint, on which the ruling Vietnam Communist Party could leverage to enhance its ruling legitimacy. Further, it also signifies a long quest of the Vietnamese people for a self-identification, explaining not only where they were from, but also directing the way they are to progress further. Accordingly, it is understandable that Vietnamese claims are imbued with historical justifications, nationalistic sentiments, realistic considerations prioritizing compliance to international norm, and state-authorized propaganda directed to domestic audience in order to converge recognition to a resilient and self-preserving Vietnamese self-image. Particularly, it is Paracel/Xisha Islands dispute, which Hanoi could maneuver to cultivate both ruling legitimacies, and earn new momentum to consolidate a new generation national identity. ${ }^{32}$

It is in this sense that the South China Sea issue has become overtly politicized and highly vulnerable to external influences. Tensions have become one convenient instrument that easily topples over efforts of all those concerned. Paradoxically, political wills, necessary for dispute resolutions, are attenuated. The issue has become more intractable, with more diversified interests and increasingly conflicting considerations.

\subsubsection{Extra-Judicialization}

On the other hand, the issue has also become extra-judicialized, in the sense that claimants, China and ASEAN, have over-estimated and mis-interpreted the role of law, and relations/dynamics between law of sea and general international law. Recalling that power asymmetry and multilateral relationships remain two features prominent in regional order in East and Southeast Asia, this should not be surprising. Also, this helps explain why varying degrees

31 Robert D. Kaplan, ASIA'S CAULDRON_The South China Sea and the End of a Stable Pacific (London: Random House, 2014), chapter III and IV. Mina Pollmann, "Government Narratives in Maritime Disputes", The Diplomat, 10 July, 2014.

32 Teh-Kuang Chang, 'China's Claim of Sovereignty over Spratly and Paracel Islands: A Historical and Legal Perspective', Case Western Reserve Journal of International Law, 23:3(1991): 399-420; David Scott, 'Conflict Irresolution in the South China Sea', Asian Survey, 52:6(2012): 1019-1042; Stein Tonnesson, "The Paracels: The Other South China Sea Dispute", Asian Survey, 26:4(2002), 145-169. 
of importance of law are assigned in policy-making in different countries in South China Sea issue.

The mainstream seems that law has been elevated to a paramount status with an unchallengeable authority. It is true, to certain extent, that a legal solution, with institutional guarantees, appears more sustainable. Yet, this trend of a law dictatorship, or to the least a law-dominating approach, is actually not much helpful in dispute resolution and conflict management. Even, backfiring reactions are triggered with unwelcome upshots of this "extra-judicialization" phenomenon.

On one hand, for ASEAN claimants, legalist narratives create the illusion that law of sea and international law can be one panacea, the magic wand that not only could resolve the dispute, but also wipe off inherent intricacies engrained in regional order-power asymmetry and multilateral relationships. Philippines fires the first shot, by bringing the issue to International Tribunal for Law of Sea (ITLOS) in January, 2013. ${ }^{33}$ Vietnam is also becoming vociferous in having recourse to international adjudication for resolutions. ${ }^{34}$ Malaysia, a claimant with a relatively moderate position, recently opines that it cannot be totally neutral and prefers a legal solution as well. ${ }^{35}$ Other non-claimant ASEAN countries also indicate, in various occasions, that international law is one mostly preferred means from their perspectives. ${ }^{36}$

33 See, supra, note 8, "The Republic of the Philippines v. The People's Republic of China"; note 10, "Notification and Statement of Claim (Philippines)".

Leaders from the Philippines and Vietnam met in February, March and May in 2014, to discuss Manila's arbitration against China. In these occasions, Vietnam had announced plans to seek legal recourse against China, which is a sign of preliminary political success for Manila. Analysis indicates that if Vietnam does file an ITLOs claim, it will no doubt face retribution from Beijing - and may be offered similar inducements to withdraw the claim. But Hanoi appears to be digging in for a long period of tensions with China, following a similar template to Manila. Meanwhile, it has sought to improve its relationships with the Philippines, India and Japan, making joint statements about the disputes. Ian Forsyth, China Brief, 14:11(2014): 11-14, accessed 20 March, 2016, http://www.jamestown .org/uploads/media/China_Brief_Vol_14_Issue_11__.pdf.

35 Jerry Harmer, "SE Asian foreign ministers voice concerns on South China Sea", Philippine Star News, 28 February, 2016; Rozanna Latiff and Ben Blanchard, A hundred Chinese boats encroach in Malaysian waters: minister, Reuters, 25 March, 2016.

36 Singapore concerns the development in South China Sea keenly. Robert Beckman, "A reply to China's stance on non-participation in South China Sea arbitration", Strait Times, o8 March, 2016; South China Sea Dispute: Singapore Leads ASEAN Talks with Beijing, International Business Times, o1 March, 2016. Indonesia also focuses their attentions on South China Sea;Jacob J., "Singapore calls for code of conduct in South China Sea", International Business Times, 28 February, 2016. Indonesia vows to prosecute Chinese 
This one-sided preference to international law among ASEAN countries, claimants or not, is somewhat surprising. Yet, it is also not much productive, in realistic terms of conflict management and dispute resolutions. On the surface, China's determinations in rejecting a multilateral resolution dominated by international law and law of sea should not be underestimated. China would not succumb to the coming ITLOS tribunal award, neither would it forego the advantageous historical asset-long histories of Chinese activities — it had in South China Sea. Further, a substantial risk of this law-dominant approach is to blind ASEAN countries from its enriched traditions that emphasize "pluralism" and "tolerance". ${ }^{37}$ Contemporary international law and law of sea, instead, has been thrived on a Westphalian international order that honored "territorial acquisition" and "monopolization of resources", respectively and exclusively, of specific occupying countries. ${ }^{38}$ In other words, "cooperation" in maritime affairs management, may have played varying roles, at different stages in governments' policy-making, under these two sets of values. In Asia, the tradition of "cooperation", along with a spirit of collaboration and collegiality, should not be abandoned.

On the China side, its approach is also not free from risk. In elaborating its South China Sea claims, China has adopted a legal formalist approach, emphasizing on the mastering of case analysis and text reading of relevant international treaties, legal documents and judicial decisions. Yet, what is awkward is these theories did not provide convincing explanations to China's behaviors,

trawler crew in South China Sea dispute, The Guardian, 24 March, 2016; Indonesia has no conflict with China in South China Sea: palace spokesman, Reuters, 23 March, 2016.

See more discussions in Jacques Bertrand, "The Double-edge Sword of Autonomy in Indonesia and the Philippines", in Multi-nation States in Asia: Accommodation or Resistance, edited by Jacques Bertrand and Andre Laliberte (Cambridge, U.K.: Cambridge University Press, 2010), 164-195; Joseph M. Fernando, The Position of Islam in the Constitution of Malaysia, Journal of Southeast Asian Studies, 37:2(2006): 249-266; Hamayotsu, Kikue, Islam and Nation Building in Southeast Asia: Malaysia and Indonesia in Comparative Perspective, Pacific Affairs, 75:3(2002): 353-75; Alfred C. Stepan, The World's Religious Systems and Democracy: Crafting the "Twin Tolerations", in Arguing Comparative Politics (Oxford: Oxford University Press, 2001), 213-253.

38 See more discussions in, Antony Anghie, Imperialism, Sovereignty and the Making of International Law (New York: Cambridge University Press, 2007), 32-114; Antony Anghie, "The Evolution of International Law: colonial and postcolonial realities", Third World Quarterly, 27:5(2006): 739-753; Prasenjit Duara, "The New Imperialism and the PostColonial Developmental State: Manchukuo in comparative perspective", The Asia-Pacific Journal, 4:1(2006): 1-18; Prasenjit Duara, Decolonization: Perspectives from Now and Then (New York and London: Routledge, 2004), 1-20, 78-100. 
in both ancient times and contemporary settings. Evidences of China's effective administrations of islands in South China Sea serve one example. They are largely deemed as vindications of historical facts of China's activities in this region. Apparently, ancient Chinese empire had not based their administration of South China Sea on the concept of sovereignty and territoriality as those under the Westphalian system. This thus explains a rather bizzare phenomenon that the Chinese claim, in which a large portion of historical justifications is discernible, appears more a preposterous chimerism. To redress this anomaly, China's scholars have dedicated time and efforts, to fill this vacuum between international law theories and China's historical behaviors, by referring to a variety of maritime activities, such as regular fishing in monsoon seasons. ${ }^{39}$ Yet, whether these historical facts could support further reification of the concept "historical right" in contemporary international law remains to be contested. ${ }^{40}$

For centuries, how dynasties and principalities had interacted, and how boundaries and territorial rights were established and practiced in this region, were based on a set of values very different from contemporary Westphalian international order. It was the Confucianistic thinking that had informed the Chinese activities in the Chinese mainland, and South China Sea. ${ }^{41}$ Further, there existed no concept of equal sovereigns among local polities, let alone exclusive territorial rights upon given territories. Instead, a hierarchy of

39 Shicun Wu, Solving Disputes for Regional Cooperation and Development in the South China Sea: A Chinese Perspective (Elsevier, 2013), 65-69. See, supra, note 6, Zou and Liu; note 7 , Zou, Historic Rights in International Law and in China's Practice.

40 It is still debatable whether China's justification which informs its strong preference to the concept of historical rights can be fitted into modern international law and law of sea. China has long been a historically dominant empire in this region. Its domination, along with certain management efforts, over South China Sea, was not challenged. Even in 1947 when the Republic of China government drew the 11-dash line, it was not encountered vigorous objections. Yet, modern international law has deemed "historical right" more at a secondary category rendering only subsidiary assistances to countries' sovereign claims. More theoretical efforts need to be done if China wants to pursue down this route that emphasizes more on histories and privileges of the initiative actor.

41 Daniel Bell, "The Making and Un-making of Boundaries: A Contemporary Confucian Perspective", in States, Nations, and Borders: The Ethics of Making Boundaries, in Allen Buchanan and Margaret Moore (eds.) (New York: Cambridge University Press, 2003), 57-85; L. H. M. Ling, "Borders of Our Minds: Territories, Boundaries, and Power in the Confucian Tradition", in Allen Buchanan and Margaret Moore (eds.) (New York: Cambridge University Press, 2003), 86-102; also see, supra, note 7, Pan, Toward a New Framework for Peaceful Settlement of China's Territorial and Boundary Dispute, and Zou, Historic Rights in International Law and in China's Practice. 
political and cultural ranking, the Chinese tributary system, and several principalities in Java Island and Indo-China peninsular whose interactions were characterized by a Mandala system of power dynamism and interactions, dictated the operation of regional order. ${ }^{42}$ In the Confucianistic thinking, boundary were established and managed not in an exclusive manner, but allowing certain flexibility of free movement of people, should they determine to leave for pursuits of better lives, or to escape from despotism..$^{43}$ Further, there were no stringent measures to prohibit, inwardly, free flow of people in border areas.

In the South China Sea scenario, it remains to be seen whether efforts by Chinese scholars seemingly can address these incongruences between international law theories and Chinese behaviors, and lend convincing supports to long-term projections of China's territorialization. It is noted that the Chinese approach is seeing international law more as serving instrumental functions, by using it as an expedient bargaining tactic in both international forums and domestic occasions. This perspective is actually quite common, a mindset prevailing not only China, but also newly-independent countries after escaping colonialist and imperialistic suppressions. In short, "doing law" and "thinking about law" are two different things. ${ }^{44}$ Yet, they can be easily confused.

It is not to repudiate either China or Vietnam and the Philippines in following the legalist formalist approach and elaborating their arguments. Yet, there can be a risk in this approach. By not having a full and good grip of cultural and societal backgrounds on which this Westphalian international system is embedded, it is likely for them to misinterpret and mis-judge on critical and structural issues. In this aspect, for example, China's refusal to participate in ongoing arbitration implies the risk that the relations between law of sea and general international law in the overall political and legal hierarchy of

42 Stanley Jeyaraja, Tambiah, The galactic polity in Southeast Asia, in Culture, thought, and social action (Cambridge, MA: Harvard University Press, 1973), 3-31; Siska Lund, "A mandala for the Southeast Asian international system," Culture Mandala: The Bulletin of the Centre for East-West Cultural and Economic Studies, 6:1(2003), 1-12; Pandu Utama Manggala, The Mandala Culture of Anarchy: The Pre-Colonial Southeast Asian International Society, Journal for ASEAN Studies, 1:1(2013): 1-13; Rosita Dellios, "Mandala: from sacred origins to sovereign affairs in traditional Southeast Asia". CEWCES Research Papers. Paper 8. 2003 .

43 Supra, see note 40.

44 Thomas Schultz, "Doing Law and Thinking about Law", Journal of International Dispute Settlement, 4:2(2013): 217-218; Randall Peerenboom, "Toward A Methodology for Successful Legal Transplants", The Chinese Journal of Comparative Law, 1:1(2013): 4-20. 
Westphalian international system may be misinterpreted. ${ }^{45}$ By insisting that territorial dispute is the 'precondition' to adjudications on its dash-line claim, on which China thus contested that the subject of arbitrations thus fall beyond the reach of ITLOS jurisdiction, implying that law of sea and general international law are two respectively operated legal regimes, between which transmission channel and communication mechanism are absent.

This Chinese understanding is based mainly on its insistence that the principle of "land dominates the sea" prescribed in law of sea should be observed. It is on this basis that China has repudiated the jurisdiction of ITLOS and the appropriateness of law of sea regime in deciding the China-Philippine arbitration. ${ }^{46}$ On the surface, it is seemingly convincing that territorial disputes should be settled in the first phase, under the egis of the "land dominates the sea" principle. Yet, two arguments cast reflective views on this contestation.

For one thing, certain provisions in the Convention are designed to accommodate judicial decisions made by other international judicial bodies regarding territorial disputes. Article 279, 287, 288 and 293 facilitate the transformation of these external decisions for internal compatibility with law of sea system. Arguably, jurisprudence of maritime territorial disputes developed in other international judicial bodies can lend informative references to law of sea and ITLOS. In this context, law of sea and ITLOS would not be in a total loss, but can have some decisions to refer to, albeit not in a formal and nominal sense. ${ }^{47}$

45 China's refusal to join the ongoing arbitration is based, mainly, on calculations of political and legal factors around these disputes. Yet, China's position paper, issued in December, 2014, sent the message that ITLOS did not have jurisdiction, because China deemed these disputes more of a territorial nature, which fell within the category of general international law. This interpretation is not totally wrong, but can be dangerous, as it implies two risks. One is that the law of sea and general international law lack appropriate channels and transformation method so that their works can be mutually accommodated. Second, the principle "land dominates the sea" may be understood as "law prioritizes the sea", by which rooms for broader deliberations that take into account interests and stakes of both land and sea are to be shrunk down. See discussions in later paragraphs, and supra, note 2 .

46 Supra, note 2, Position Paper (China), para. 3.

47 This is due to the lack of a stare decisis principle in international adjudication system. Yet, international judicial bodies will consider cases made by other bodies in due course of their decisions. See more discussions in, Gilbert Guillaume, The Use of Precedent by International Judges and Arbitrators, Journal of International Dispute Settlement, 2:1(2011): 5-23; M. P. Van Alstine, Stare Decisis and Foreign Affairs, Duke Law Journal, 61:5(2012): 941-1024; C. H. Schreuer, The Applicability of Stare Decisis to International Law en English Courts, Netherlands International Law Review, 65:2(1978): 234-238; Mohamed Shahabuddeen, Precedent in the World Court (Cambridge, U.K.: Cambridge 
Second, jurisprudence of maritime territorial disputes made by other international judicial bodies would, recursively, help law of sea and ITLOS to establish an apparatus of determining factors and a decision pattern. It is indeed true that considerations vary, when ITLOS and other international judicial bodies decide on cases, depending on distinctive institutional characteristicsbe it public or private, regular or ad hoc-intended policy goals, organizational cultures, and contexts of cases. ${ }^{48}$ Yet, these decisions are likely to render interactive influences, re-configuring the others from a remote but not unapproachable manner. For instance, the role of an island in delimiting territorial seas, EEZ and Continental Shelf is different and can be varied from case to case. ${ }^{49}$ Generally, the size, distance from the coast, if the islands can sustain economic activities, its impacts on navigation and on the equity of partitioning of maritime zones, constitute different decision patterns in various cases. All these factors cast critical, if not decisive, impacts on how an international judicial body, including ITLOS, decides on a case of maritime boundary delimitation and on maritime zoning. In this aspect, it is self-proven that law of sea and ITLOS continue to develop by receiving these external influences in due course with a constructive manner.

University Press, 1996), 97-109, 209-233; Shabtai Rosenne, The Law and Practice of the International Court, 1920-1996 (The Hague: Nijhoff, 1997), vol. II and III; Mohamed Shahabuddeen 'Consistency in Holdings by International Tribunals', in Nisuke Andao, Edward McWhinney, and Rudiger Wolfrum (eds), Liber Amicorum Judge Shigeru Oda (The Hague: Kluwer, 2002) 633-50; R. H. Steinberg 'Judicial Lawmaking at the WTO: Discursive, Constitutional, and Political Constraints', The AmericanJournal of International Law, 98:2(2004): 247-275.

48 Benedict Kingsbury, "Foreword: Is the Proliferation of International Courts and Tribunals a Systemic Problem?," New York University Journal of International Law \& Politics, 31(1999): 679-696; Chester Brown, A Common Law of International Adjudication (New York: Oxford University Press, 2007), available on Oxford Scholarship Online, accessed 20 March, 2016, http://www.oxfordscholarship.com/view/10.1093/acprof:oso/9780199206506.001.0001/ acprof-9780199206506; August Reinisch, The Proliferation of International Dispute Settlement Mechanisms: The Threat of Fragmentation vs. the Promise of a More Effective System? Some Reflections From the Perspective of Investment Arbitration, in International Law between Universalism and Fragmentation: Festschrift in Honour of Gerhard Hafner, edited by Isabelle Buffard, James Crawford, Alain Pellet and Stephan Wittich (The Netherlands: Brill, 2008), 107-126; Gary Born, A New Generation of International Adjudication, Duke Law Journal, 61:4(2012): 775-879; Roger P. Alford, "The Proliferation of International Courts and Tribunals: International Adjudication in Ascendance", American Society of International Law Proceedings, 94(2000): 160-165, 160. Supra, see, note 14 . 
Accordingly, China's contestation that first, prioritizes the settlement of territorial disputes to maritime limits disputes and second, denies itLos jurisdiction and application of law of sea, is understandable, yet needs further calculation. This is due to the possibility of misinterpreting the relations and interactions between law of sea and general international law in the overall political and legal hierarchy of contemporary international order.

Amid this conundrum, a question needs to be addressed before attempting to provide further thoughts of solutions. How should the South China Sea dispute be construed? What lies behind these territorial contestations that continue to fuel the hostility? In a regional environment that has embraced Westphalian rules and corresponding practices, China and ASEAN countries actually are in an uphill battle searching for a solution. Before making proposals in later section, some re-contemplations of the South China Sea dispute merit discussions.

\subsubsection{Beyond Territorial Claims}

Briefly put, the real issue in South China Sea is about the wrestling in the agenda-setting power that aims at shaping regional maritime order in coming decades, in both political and legal scenarios. The wrestling is between regional power, China and one most influential global power in this region since the end of World War II, the U.s. Situating under this context, ASEAN claimants' wrestling in South China Sea is actually an extension of this China-Us confrontation, with ASEAN claimants being U.S. proxies to different extents. The trend seeing further territorialization of the dash-line claim triggers immediate concerns. For the U.s., as a gatekeeper of both the dominating Westphalian international order and a rule-maker in this region, its worries are comprised of concerns of navigation freedom, maritime security and peaceful settlement of disputes..$^{50}$

Yet, cynically put, if these interests are at stake, not only the U.s., but also the international community as a whole, should pool their efforts together to address these issues. It is in this context that the essence of the South China Sea issue actually regards more the wrestling of agenda-setting and rule-making power between regional power, China and global hegemony, U.s. Put differently, if this dash-line claim had been fleshed out and brought to the frontline practice, this would risk the U.s. not only significant costs of losing its Asian and ASEAN alliances, but also depriving the U.s. of the agenda-setting authority over regional orders in coming decades in this region.

5o These, arguably speaking, give the u.s. a relatively weak legal ground to justify its forceful presence, in whatever manifestation, in the South China Sea issues. 
In this sense, what underlies the South China Sea issue is an unfinished tugof-war between newly-established Asian countries - which have embarked on a tantalizing journey after the end of World War II in quest for new national identities, leverages and positions better reflecting their growing selfconscience of their indigenous cultures and traditions - and western powerswhich have been flourished and benefitted for centuries from the globe wide institutionalization of the Westphalian system and has sought to cement and extend the privilege already garnered. When put in a neutral term, the South China Sea tension can also be termed as revealing a trend which is currently taking place, that of transformation of the world order from a Westphalian system to one more inclusive of different cultures, values and discourses with diversified perspectives and varied justifications.

Therefore, even when holding high the banner of international law, legal overtures of ASEAN claimants are still controversial. By relying heavily on legal discourses, flexibility and rooms for maneuvering, at times in extra- and nonlegal scenarios, are quickly shrinking. Further, to resort to judicial means for dispute resolution at international level, is time consuming and financially costly. Put frankly, by emphasizing, with great public fanfares, on international judicial settlement, ASEAN claimant governments may run the risk of shrugging off how lives of people in littoral communities may have been impacted, but addressing their attentions more on the credit, legitimacy and political victories of ruling elites in claimants' capitals. In this context, while not rejecting legal channels which can provide sustainable resolutions, pragmatic approaches need to be considered simultaneously. Put sharply, pragmatic thinking can not only meet the demands of people living in the frontline and bearing direct costs of confrontation, but also helps to trigger changes in people's mindset so as to facilitate a better environment for conflict management, risk-sharing and eventually, dispute resolution.

It is under this context that the recently proposed initiatives of building a Maritime Silk Road by China should be considered. The pragmatic mindset and substantial benefits entailed in this initiative should not be easily shrugged off.

\section{Reviving a Collaborative South China Sea via 21st Century Maritime Silk Road}

Indicated in state media, Xinhua News, The 'One Belt, One Road' initiative (Овов) starts with the idea that nearby countries in Central Asiaspread along the traditional Silk Road—could benefit from more transport 
infrastructures, some of which China could finance bilaterally. ${ }^{51}$ Further, the idea of a Maritime Silk Road (the Road Plan hereafter) — that is, the expansion of infrastructures along the seagoing routes from the Chinese coast through Southeast Asia to the Indian Ocean and all the way to Europe is added to further replenish this ambitious proposal.

Succinctly put, as grandeur as the slogan may be, challenges have been unpicking exactly what it means. Two points merit reiterations. For one thing, it is not targeting only a single trading route. Rather, it is about building networks of connectivity. The geographical linkages envisaged by the "Belt" (in the northwest) and the "Road" (in the southeast) are to multiple locations. Second, physical infrastructure of connectivity points is a critical, but not a solely main content. Rather, connectivity can be elaborated in multiple terms of trade, investment, finance, and flows of tourists and students. ${ }^{52}$

$5^{1} \quad$ Xinhua News, "China's Initiatives on Building Silk Road Economic Belt and 21st Century Maritime Silk Road", accessed 20 March, 2016, http://www.xinhuanet.com/english/ special/silkroad/index.htm; Tim Summers, What exactly is 'one belt, one road'? Chatham House, 71:5(September 2015), accessed 20 March, 2016, https://www.chathamhouse.org/ publication/twt/what-exactly-one-belt-one-road; Lucy Hornby, China's 'One Belt One Road' plan greeted with caution, Financial Times, 20 November, 2015. There exist criticisms too. In English the name is allegedly clunky and misleading, with which confusions could be most effectively dismissed via actual implementation efforts. In other words, this initiative has been fleshed out via detailed arrangement later unfolded in March, 2015. State Council, "China unveils action plan on Belt and Road Initiative", People's Republic of China, 28 March, 2015, accessed 20 March, 2016, http://english.gov.cn/news/ video/2015/03/29/content_281475079526119.htm.

52 "Infrastructure connectivity a priority in Belt and Road Initiative", Xinhua News, 28 March, 2015; "Xi on 'Belt and Road': Not China's solo but inspiring chorus", Xinhua News, 28 March, 2015. Despite this rather exclusive narrative and high-level political messaging, it is contested that this initiative is not much new than might first meet the eye, when digging beneath the surface of Chinese policymaking which reveals more continuity in their promulgation and promotion. See further, David Dollar, "China's Rise As A Regional And Global Power: The AIIB and The 'One Belt, One Road', Horizon, 4(Summer 2015): 162-172, accessed 20 March, 2016, http://www.brookings.edu/research/ papers/2015/07/china-regional-global-power-dollar. Also, see supra, note 35, Summers, What exactly is 'one belt, one road'. Criticism of this initiative goes like this, that The scale of the vision is such that it will ultimately be the responses of other countries that are key to deciding whether the coming decade sees the sort of intensified networks of connectivity between China, Asia and Europe that are at the heart of the 'one belt one road' vision. 


\subsection{Situating South China Sea in the Maritime Silk Road in the 21st Century}

A Maritime Silk Road in the 21st century is believed to be inspired by historical maritime trading routes from southeast coastal China through South China Sea and beyond, by extending these routes to continents and countries where trade volumes are currently small, but with potentials of consistent growth, such as East Africa and the Mediterranean area. Besides this historical legacy, quickly deteriorating conditions in China's neighbouring context and South China Sea also shed decisive lights on how this modern maritime trade route is to be unfolded.

The South China Sea issue is now enmeshed in a malicious cyclic pattern, getting involved not only claimants, but also extra-regional stakeholder countries. Proliferation of actors have, to a considerable degree, rendered the dispute even more intractable, as any single compromise between two parties may have spill-over effects upon third countries. The China-Philippine arbitration initiated in January, 2013 continues to highlight this dilemma. Inter alia, a trend of territorialisation in China's dash-line claim and island-reclamation works, ${ }^{53}$ feature what have been worrying ASEAN claimants to the uttermost extent.

Under this context, how would a proposal of building a maritime trade route, the Road plan, interact with the festering South China Sea disputes?

Succinctly put, how would the ongoing trend of territorialisation of the dash-line claim impact the Road plan? By territorializing the dash-line claim,

53 Beginning in the second half of 2014, China started island-reclamation and construction works in South China Sea, raising concerns of China's intentions and future plans along with these works. China claims that these works are for peaceful and non-military usage, as indicated in words of the spokesperson of China's Foreign Affairs Ministry on 9 April, 2015. Quoting the spokesperson's words, According to Hua, China's "maintenance and construction work" on the Spralty/Nansha islands has the following purposes:

$[O]$ ptimizing their functions, improving the living and working conditions of personnel stationed there, better safeguarding territorial sovereignty and maritime rights and interests, as well as better performing China's international responsibility and obligation in maritime search and rescue, disaster prevention and mitigation, marine science and research, meteorological observation, environmental protection, navigation safety, fishery production service and other areas.

Ministry of Foreign Affairs (China), Press Conference of Spokesperson, Hua Chunying, 9 April 2015. Zhang Yunbi, "FM dismisses blame on China's land reclamation in South China Sea". The China Daily, 8 March 2015; Paul Vale, "Beijing Constructs Chain Of Artificial Island Fortresses In Disputed Region Of South China Sea", The Huffington Post, 20 February 2015. 
is China to circle the waters falling within the line, around $80 \%$ of the sea, by exercising exclusive sovereign rights, monopolized enjoyment of maritime resources and self-centred national security measures? Following this theme, how would China persuade ASEAN countries that its development is benign and of a mutually beneficial characteristic as often prescribed in its policy discourses? Taking one step further, in the scenario that China continues to push through its aspiration of territorializing South China Sea, would this impede, in whatever manifestation, the realization of the Road plan?

In this sense, a structural issue is looming behind the scene. Had China failed to integrate between its South China Sea claim and the Road plan - the integration being that the Road plan is able to attract and strengthen ASEAN claimants' confidence, despite a territorialized South China Sea at the helm of Beijing-implications can be dampening. One least-desired upshot is that China would lose the credit needed in due course of the transition of its role as a regional reliable power, with great development potentials and outlooks of promoting co-prosperity among neighbouring countries via the Road plan. With a failure of sealing this recognition, would China's seemingly contradicting positions-adamant-ness in safeguarding its South China Sea claim and compromisive-ness in getting all those interested on board the Road planrecursively cement the paradox of East Asia-that economic and political prospects are to be counted on different countries, as the former goes to China, and latter, the U.s.? With this fact turning a desperate reality, would China's further development at both regional and international level be overshadowed and compromised?

It is these issues, all bundled-up, that lead to the observation that failing a constructive management in South China Sea situation, benign intentions and political credits of the Road plan would be attenuated. Further, the Road plan may eventually lapse into mere propaganda used for mobilizing political grouping consisted of countries following China's lead. Without corresponding national prowess, and with looming risks of opportunist calculations that underlie these countries' supports, these groupings would not sustain. Under such a context, not only the Road plan that is likely to be aborted, but also China's greater ambitions of establishing a new type of great-power relations with the U.S. and other international subjects may also be shattered.

\subsection{Proposals: Concepts and Implementation Initiatives}

The connection between the South China Sea issue and the Road plan has been established. Yet, it is seemingly a hasty conclusion that China is to claim its dash line as a maritime boundary, as what is termed under Westphalian 
international order, so that it is able to facilitate an exclusive and absolute management over these great swathes of water. An in-depth look of Chinese statements reveals that traditional understanding of how sovereignty and territorial rights are to be understood and exercised is still looming behind China's position. Further, this legacy is earning momentum in shaping its policy-making and negotiation strategy. Among all contributing factors, China may consider a concept, by borrowing ancestors' wisdom, that of an open-end maritime boundary, upon which sovereignty over land features and jurisdiction rights addressing maritime order in the region could be operationally facilitated for an altruistic purpose. Intriguingly, this concept of an open-end maritime boundary may lend critical helps to on one hand, achieve China's intended goals of the Road plan, while alleviating world's concerns of China's ambitions, however perceived, to hegemonic global leadership.

\subsubsection{The Dash Line as an Open-end Maritime Boundary}

Of primary importance is to operate the dash-line claim, even as a maritime boundary in Chinese concept, with an open-end manner. In other words, sovereign right and the entailed management of maritime spaces defined by this dash-line maritime boundary should be conducted in a flexible, open-end, inclusive yet efficient manner. That said, its flexibility, openness, inclusiveness and effectiveness should be comprised of following constituents: nonexclusive spatial management; a goal of providing public goods, such as maritime security; adoption of a rationae personae jurisdiction as a complementary means to strengthen human security and protection of lives on the sea; and consistent negotiations on joint development of maritime resources development. Yet, all should be formulated and conducted with clear consciousnesses that honour the principle and goal stipulated in law of sea and general international law.

\subsubsection{Sophistication and Subtleties of Management}

A panoramic view shows that success of this approach relies on China's capability in delivering substantial outcomes under this quadruple framework. It would thus be a performance with sophistication to accommodate incongruences between universal dominating norms and exceptional regional experiences, and credibility of its policies accumulated via subtleties of regional management tactics.

First, in order for the dash-line claim — deemed as a maritime boundarynot being turned as a political burden and a legal hazard, it should be operated with an open-end manner. The underlying logic is that operation of the 
dash-line maritime boundary is to be informed with the concept of "border control", not "border security". 54

The former, border control, is of a broader nature, to which the latter, border security, is incorporated. Further, border controls generate both effectiveness and efficiency via its management measures, with great potentials to alleviate disputes and transform rivalries into co-prosperity. In practice, border control covers an array of measures, ranging from border security maintenance in the fore points, to negotiations and conversations in local communities and national capitals. Regular exchanges in border areas-as maritime rescue assistance, disaster relief and replenishment aid at peaceful times on the sea-also help achieve peace and stability in South China Sea. Instead, those focusing on border security are shaped by a zero-sum mindset, which easily triggers a devastative conflict enmeshing everyone concerned. Succinctly put, border control measures are to frame a symbiotic relationship with all involving parties, and to transform confrontations into mutual developments.

Put succinctly, it is a concept of "border control", not "border security" that helps inform, and complete this open-end management. Unlike "security" that connotes an inherently exclusive attitude toward how spatial management is exercised, open and inclusive management would only be possible, if a broader term of "control" is emphasized. In this sense, China's dash-line claim would not be mis-understood that it is a disguise under which China intends to revive its tributary system, by circling South China Sea under its sole management exclusive to other regional countries, and a subsequent corollary of a Chinese dictatorship in a new regional order.

To better facilitate this open-end management approach, monitoring and surveillance measures should be allowed, in order to detect and deter, timely, dangers and threats to maritime security in South China Sea. Meticulous

54 J. R. Victor Prescott and Gillian D. Triggs, International Frontiers and Boundaries: Law, Politics and Geography (Martinus Nijhoff, Netherlands, 2008): 23-90; J. R. Victor Prescott, The Geography of Frontiers and Boundaries (London and New York: Routledge, 2015), 33-55; Ladis K. D. Kristof, The Nature of Frontiers and Boundaries. Annals of The Association of American Geographers, 49:3(1959): 269-282. Regarding the evolution of boundary in Southeast Asia, see R. L. Solomon, "Boundary Concepts and Practices in Southeast Asia", World Politics, 23:1 (October, 1970), 1-23; Yong Leng Lee, Southeast Asia: Essays in Political Geography (Singapore: National University of Singapore Press, 1982), 9-16; Yong Leng Lee. "The Colonial Legacy in Southeast Asia: Maritime Boundary Problems", Contemporary Southeast Asia, 8:2 (September, 1986): 119-130; Amitav Acharya, "Imaging Southeast Asia", in The Making of Southeast Asia: international relations of a region (Ithaca, N.Y.: Cornell University Press, 2013), 51-104; Alastair Lamb, Asian Frontiers (New York: Frederick A. Praeger, 1968), 39. 
attention should be accorded to security concerns under the initiative of both China and ASEAN claimants. In this aspect, joint maritime patrols can facilitate basic demands of the maintenance of maritime security. Yet, for fishing and maritime resource development activities, the two flashing points for skirmishes on the sea, intricate deliberations are required.

For fishing and other resource development activities, joint development may provide an alternative, when stipulations prescribed in law of sea and general international law seemingly are at dead end in delivering their intended management outcomes. Not to defy or repudiate law of sea, in an area like South China Sea where issues have become highly politicized and overtly judicialized, joint development can better accommodate all involved to have their shares and burden their duties. The essence of this model lies in a timely reminding that it is a spirit of collaboration and collegiality that has informed and shaped these activities, instead of an exclusive, monopolized theme that dictates the apportioning of resources under law of sea framework. The latter, most likely, generates backfiring impacts, as what has been witnessed in past decades in South China Sea. ${ }^{55}$

Besides, the concept of "joint development" should be deemed as earning normative momentums via decades of international recognitions and practices. ${ }^{56}$ Voluminous international treaties and agreements, bilateral or

55 For decades, ASEAN countries have been engaged in a "push the envelope" approach in South China Sea issues. They were concerned if a stronger China would resolve the issue all for once by use of force. What they concerned the most, however, was whether they would be blocked from conducting maritime resource development activities in South China Sea. As a result, they were racing at adopting unilateral measures, for the fear that they would loss the chance once China got further developed. Recent years, the South China Sea situations get further deteriorated because of a compound of factors, such as China's new moves-island reclamations and patrol by China Coast Guard-and the escalating U.s.-China wrestling. Accordingly, several of ASEAN claimant countries are engaged in defense diplomacy, and a race-up of military capability building. The Philippines announced in December 2014 that a sum of 885 million U.s. dollar will be used for force modernization program. Several countries, including France and Korea, have submitted bids for procurement deals. This is opined by Rear Admiral Caesar Taccad, head of the Philippine Navy's weapon systems, on 17 December, 2014. Vietnam was also involved in an intense round of defense diplomacy in end 2014 and early 2015, involving naval port visits, dialogues in a miscellaneous defense-related issues and exchanges of high-level delegations. Inter alia, a trend to upgrade defense dialogues, and to broaden the scope of cooperation merits attentions.

$5^{6}$ The concept "joint development" connotes cooperation between sovereign states, an international obligation which has been enshrined in voluminous international treaties, conventions and legal documents. Examples are like United Nations Charter, Chapter vi 
multilateral, have all prescribed this concept as a primary alternative to legalist means. Despite various manifestations in treaty texts, it is the spirit of cooperation and collegiality that breaks the stalemate and thaws the hostility. In South China Sea, joint development serves a similar role, with which effective and pragmatic maritime resources development activities can be conducted.

Another critical constituent that requires deliberations is a rationae personae jurisdiction in foreign Exclusive Economic Zones (EEZs).

Law of sea regime adopts a ratione materiae jurisdiction-prescribing prohibitions and allowable activities based on the regulated subject, the activityin areas beyond territorial waters. Of particular importance is the EEZ, which can be extended up to 200 miles from national coasts. Yet, a drawback shows that this ratione materiae jurisdiction may not be so efficient and effective in delivering designed management outcomes.

In foreign EEZs, the right to marine resource development is attributed solely to coastal countries. Yet, regarding activities that come under EEZ regulations (under the initiative of coastal countries), the system is silent in whether activities, which have a non-resource-relevant or non-resource-oriented purpose, yet causing inadvertent and un-intended impacts on the marine environment, should also be subjected to coastal countries' regulations. In other words, a loophole beyond the reach of this raitone materiae jurisdiction exists, namely maritime activities causing inadvertent and un-intended damaging impacts on the marine environment. A jurisdiction designed and directed against regulated objects, such as resource-oriented activities (the raitone materiae jurisdiction), would not be able to address this loophole. EEz rights accorded to coastal countries fall into this category, in which jurisdiction is directed at certain activities, mainly resource-oriented. For incidents conducted on extraresource purposes, yet causing harms to the marine resource and environment, law of sea system cannot regulate them. This raises an inquiry, if and how the regulation jurisdiction in EEZ should be adjusted.

This issue of jurisdiction incompetence sends an alarming message, signalling that law of sea, actually, serves more the interest of coastal countries. Coastal countries are - what they have been asked for mainly—exercising a ratione-materiae jurisdiction in Eezs and continental shelves, in mostly a

(Pacific Settlement of Disputes, Article 33 to 38), and a General Assembly Resolution, "Declaration on Principles of International Law concerning Friendly Relations and Co-operation among States in accordance with the Charter of the United Nations" adopted on 24 October, 1970, A/RES/25/2625, accessed 20 March, 2016, http://www .un-documents.net/a25r2625.htm. 
unilateral manner, which thus exonerates them responsibilities of comprehensive policy-making and coordinating among miscellaneous maritime issues between adjacent countries. Provisions calling for inter-state, regional and international cooperation in law of sea lack strong institutional and legal teeth for actual implementation. Further, foreign states responsible for their vessels' activities - a ratione personae jurisdiction-in coastal countries' EEzs are not assigned appropriate roles to tackle their vessels' encroachment activities and illegal fishing.

In an era when increasing maritime activities in foreign waters and explosive actors on the sea becomes more common, this ratione materiae jurisdiction is becoming more incapable of due management of a variety of issues on the sea. In this aspect, one alternative is to adopt the ratione personae jurisdiction, as a complementary means. Better management outcomes would be possible, in foreign waters, when jurisdictions can be exercised on both regulated activities, ratione materiae and the people conducting them, ratione personae. It is in this sense that when activities are not intended for resource purposes, but have caused considerable harms on the marine environment, coastal countries would have more tools to redress these wrongs, including asking foreign countries responsible for regulating these people to share due management responsibilities and correct environmental harms.

For example, if flag nationality country could strengthen the monitoring and recording of vessels' activities in foreign EEzs, grey numbers in Illegal, Unreported and Unregulated (IUU) ${ }^{57}$ fishing and incompetence of coastal countries in IUU management may be more effectively redressed. ${ }^{58}$

57 The definition of IUU fishing is promulgated by the United Nations Food and Agriculture Organization, which is then adopted by the International Plan of Action to Prevent, Deter and Eliminate Illegal, Unreported and Unregulated Fishing. According to the definition of the IPOA, IUU fishing can be conducted in EEzs, high seas and areas where there is no management measure applicable. In EEZ areas, the coastal countries' capacity of monitoring, control and surveillance constitute a core issue in terms of management efficacy. Frank Meere and Mary Lack, Assessment of Impacts of Illegal, Unreported and Unregulated (IUU) Fishing in the Asia-Pacific, Sustainable Fisheries Management. AsiaPacific Economic Cooperation Fisheries Working Group, 2008. 5 .

58 A case in ITLos also addresses this issue. International Tribunal for Law of Sea, "Request for an advisory opinion submitted by the Sub-Regional Fisheries Commission (SRFC)", Advisory Opinion, case no. 21, 02 April, 2015, accessed 20 March, 2016, https://www.itlos .org/en/cases/list-of-cases/case-no-21/. 
This article intends to view the South China Sea issue in a broader context of the continuing development of China to become a regional and global power with corresponding credits and deserved reputations, a new development plan for China in international platforms. What characterize this context are a new momentum and a threshold test. The former, the Maritime Silk Road plan (as a constituent to the "One Belt One Road" Initiative), is to establish a developmental apparatus which would activate and lead the way forward of this new development plan. The latter, the South China Sea issue, has become one critical test. In a short term, the South China Sea issue holds the key if this Maritime Silk Road plan can be unimpededly laid out, while in the long run, it also serves to verify if China could win itself more leverages in both agendasetting power in regional order and credits as a reliable benign regional and global power.

The South China Sea issue and Maritime Silk Road plan crisscross, in the sense that the South China Sea issue may cast weighing influences of further realization of the Maritime Silk Road plan. In particular, the trend of territorializing the dash-line claim by China generates direct impacts on the next step of the Maritime Silk Road plan.

The South China Sea issue has become more and more intractable, when situations are now overwhelmed with an over-politicization trend. There lies the possibility of over-emphasizing the role of law (over-judicialization), or mis-interpreting the relations between law of sea regime and general international law (under-judicialization). Inter alia, territorialization of the dash line - making the dash line both a maritime limits standard and a boundary in South China Sea - can be considered if China constructed it by, first, cultivating the sophistication to accommodate incongruences between a universally dominating system and exceptional regional experiences, and second, enhancing the credibility of its policies accumulated via subtleties of regional management tactics. Put in details, key issues are like operating the dash line as an open-end maritime boundary, with a policy goal of providing maritime security, by using supplementary means such as a jurisdiction incorporating both a ratione materiae and personae focus, and joint development as a major template for maritime resource development activities.

This approach is worth considering, recalling that regional maritime order used to be maintained, by constructing a symbiotic relationship featuring pluralism and mutual tolerance. Only by operating this dash line, in an open-end, effective and flexible manner could it lend a helping hand to the Maritime Silk 
Road plan and further aspirations of Beijing to be a reliable regional and global power.

Yet, the South China Sea dispute clearly has shown a picture of diversified interests with sometimes conflicting considerations. Also, how the public perceives this issue depends heavily on parochial interests of governmental agents which have the power to control access to these islands. One common worry for all those involved is to make clear distinction between real stakes and those serving for lip services and passionate sentiments that appear as double-edged sword. The underlying interests are economic, geopolitical and strategic. Yet, they can be easily ratcheted up or down, and to be transformed to emotions with nationalistic significance to suit political calculations for certain groupings. These frames always end up with counterproductive upshots. In this sense, the Maritime Silk Road plan, which emphasizes common interests of co-prospect and co-existence, helps provide an alternative resolution. It features that disputes in South China Sea should not be up-scaled frenetically, with the can-be-hazardous enthusiasm prioritizing sovereignty and territoriality under a disguise of self-denial of past histories and the disappointment to the governance of incumbent administrations.

The South China Sea dispute has become highly politicized. Yet, institutionalization efforts for conflict management and eventually, dispute resolution, remain relatively underdeveloped. The threat is imminent and pressing. Put simply, the more politicized and judicialized the South China Sea issue becomes, the more difficult it can be tackled effectively and efficiently. Yet, the Maritime Silk Road plan shed lights on how the South China Sea issue can be redressed, by providing an alternative that goes beyond these over-politicized and overtly-judicialized hurdles. In other words, it points a direction, that disputes can be resolved, eventually if not immediately, via a developmental plan that prioritizes cooperation and mutual prospect, by respecting a spirit of collaboration and collegiality that has long engrained in this region.

The reality is, by not being able to tackle the South China Sea issue, this Maritime Silk Road plan and its intended goals, may run the risk of being further attenuated, dis-credited and to the extreme, debilitated. Creative thinking, senses of rationality and practicality and an open-mind attitude are what is mostly required for sustainable and beneficial resolutions. Before these facts turn to be dire realities, they'd better be dealt with meticulously and seriously. 